\title{
Abiotic and Biological Suppression of Phytophthora parasitica in a Horticultural Medium Containing Composted Swine Waste
}

\author{
E. J. Fichtner, D. M. Benson, H. G. Diab, and H. D. Shew
}

Department of Plant Pathology, North Carolina State University, Raleigh 27695.

Accepted for publication 3 March 2004.

\begin{abstract}
Fichtner, E. J., Benson, D. M., Diab, H. G., and Shew, H. D. 2004. Abiotic and biological suppression of Phytophthora parasitica in a horticultural medium containing composted swine waste. Phytopathology 94:780-788.

Horticultural potting media have been amended with compost to enhance biological suppression and with $\mathrm{Al}_{2}\left(\mathrm{SO}_{4}\right)_{3}$ to enhance abiotic suppression of plant pathogens, but these factors have not been simultaneously incorporated into the same medium. In this study, the efficacy of aluminum (Al)-amended potting medium containing 20\% composted swine waste (CSW) was assessed for control of Phytophthora parasitica (syn. P. nicotianae), a soilborne pathogen causing damping-off of many horticultural bedding plants. Steamed and unsteamed media were amended with no $\mathrm{Al}$ or $\mathrm{Al}$ at $0.0079 \mathrm{~g}$ of $\mathrm{Al} \mathrm{g}^{-1}$ of medium with an $\mathrm{Al}_{2}\left(\mathrm{SO}_{4}\right)_{3}$ so-

durations beginning $0,6,13$, and 21 days after $\mathrm{Al}$ amendment. The number of sporangia produced on infested leaf disks was assessed. A similar experiment was conducted to determine the effect of steaming and $\mathrm{Al}$ amendments on pathogen populations. Medium treated with the $\mathrm{pH} 4$ solution consistently reduced sporangia production between 38 and $65 \%$ on day 0 , but no $\mathrm{Al}$ effect was noted at subsequent time points. The $\mathrm{pH} 6$ amendment did not consistently affect sporangia production. Exchangeable Al levels decreased over time, and abiotic suppression was only observed at $>2 \mu \mathrm{M} \mathrm{Al} \mathrm{g}^{-1}$ of medium. Pathogen populations were occasionally affected by steaming and Al. Sporangia production in unsteamed medium was reduced by $50 \%$ on leaf disks buried on days 6,13 , and 21 , but not on day 0 . Al amendment of a $20 \%$ CSW potting medium enhanced suppression of $P$. parasitica and abiotic suppression occurred before biological suppression developed.
\end{abstract} lution at either $\mathrm{pH} 4$ or $\mathrm{pH} 6$. Infested leaf disks were buried for 2-day
The scarcity and rising cost of sphagnum peat moss (9), coupled with the need to reduce and utilize the hog waste from North Carolina's growing swine industry, has prompted research on the incorporation of composted swine waste (CSW) into an organic potting medium (12). Compost is produced from the degradation of organic waste materials by diverse microbial populations (14). Compost is of value to the agriculture and horticulture industries due to its chemical and physical properties that enhance soil fertility, structure, water-holding capacity, and overall plant health $(9,14,34)$, and also for its biological properties, which may be utilized to suppress plant disease.

A wide variety of composts, generated from animal and plant waste materials, have been studied for suppression of plant diseases $(2,7,8,14,27,33)$. Biological suppression of pathogens in compost results from microbial activity developing during the composting process (14). The decompositional status of a medium affects the level of biological suppression offered by a compost-amended medium $(6,17)$. Highly decomposed organic matter, such as sphagnum peat moss, does not support high microbial activity (18) and tends to be conducive to diseases caused by soilborne plant pathogens. For example, Pythium ultimum was more suppressed in medium containing less decomposed organic matter than in a highly decomposed medium (6). Suppression of Phytophthora cinnamomi was observed in media amended with chicken manure compost containing high microbial activity and high populations of endospore-forming bacteria (2). Assessment of microbial activity was used as a predictive measure to determine the potential level of suppression of a potting mix for management of root rot on poinsettia caused by Pythium aphanider-

Corresponding author: H. D. Shew; E-mail address: david_shew@ncsu.edu

Publication no. P-2004-0503-02R

(c) 2004 The American Phytopathological Society matum (6). In fact, media amended with composted municipal sludge requires lower compost content $(2.5 \%, \mathrm{vol} / \mathrm{vol})$ than a similar medium containing composted pine bark $(20 \%$, vol/vol) to induce suppression of Pythium damping-off. This was attributed to the higher level of microbial biomass in the composted municipal sludge $(8,18)$. On the other hand, heat treatment required to kill fecal pathogens in sewage sludge may render a medium conducive to Rhizoctonia solani (23). Extending the curing time of such composts, however, can allow for microbial re-colonization of the medium and a resurgence of suppression to $R$. solani (23).

Recently, Diab et al. (12) studied pathogen suppression in potting media containing CSW produced by two different compostmanagement practices. One of the composts studied, CSW1, suppressed Pythium damping-off of cucumber and preemergence damping-off of impatiens caused by $R$. solani. Fresh or uncomposted swine waste was conducive to disease. The exact mechanisms of pathogen suppression in CSW1 are unknown; however, medium containing 20\% CSW1 had a more diverse microbial community and contained more fluorescent pseudomonads, heterotrophic fungi, endospore-forming bacteria, and oligotrophic bacteria than that of CSW2. Furthermore, CSW1 exhibited a greater structural diversity, evidenced by BIOLOG analysis as well as microbial activity tests (12).

Although biological suppression of plant pathogens has been the focus of most studies in peat-based potting mixes, abiotic suppressive factors also have been incorporated into horticultural potting mixes. For example, aluminum ( $\mathrm{Al}$ ) has been incorporated into peat moss-based potting media for control of damping-off of ornamental bedding plants caused by Phytophthora parasitica $(3,4)$. Benson (4) controlled preemergence damping-off of snapdragon, vinca, and petunia in a peat and vermiculite potting medium with the addition of $\mathrm{Al}_{2}\left(\mathrm{SO}_{4}\right)_{3}$. Disease control in this system was observed at $\mathrm{KCl}$-exchangeable $\mathrm{Al}$ concentrations as low as $2.03 \mathrm{meq} \mathrm{Al}^{+3}$ per $100 \mathrm{~g}$ of medium. Aluminum was not 
phytotoxic to any of the bedding plants studied, indicating a differential sensitivity of the pathogen and host to Al.

Focusing on the chemistry of $\mathrm{Al}$ in organic systems, Fichtner et al. (13) further investigated the Al-mediated suppression of $P$. parasitica var. nicotianae in a peat-based medium. Limed peat was amended with $\mathrm{Al}_{2}\left(\mathrm{SO}_{4}\right)_{3}$ solutions and infested with $P$. parasitica var. nicotianae. Pathogen populations were reduced by at least $65 \%$ in $\mathrm{Al}$-amended media and suppression was observed at $\mathrm{K}$ exchangeable $\mathrm{Al}$ concentrations as low as $1 \mu \mathrm{mol} \mathrm{Al} \mathrm{g} \mathrm{g}^{-1}$ of peat at a $\mathrm{pH}$ of $>5.0$. In the peat system, the presence of organic acids alters $\mathrm{Al}^{3+}$ activity by the formation of $\mathrm{Al}$-organic acid complexes (35). The conditional formation constants for Al-organic matter complexes increase with $\mathrm{pH}(16)$; therefore, the elevated $\mathrm{pH}$ of the peat system enhanced the affinity of peat for $\mathrm{Al}$. Most $\mathrm{Al}$ ions bound to organic matter are hydrolyzed and act as a buffer against changes in $\mathrm{pH}$ (15). Given the high Al-binding capacity of peat and the low concentrations of exchangeable $\mathrm{Al}$ in the system, it is possible that the organically bound $\mathrm{Al}$ or an $\mathrm{Al}(\mathrm{OH})_{3}$ precipitate may have been responsible for pathogen suppression (13). The suppression of pathogens in Al-amended peat differs from the frequently documented suppression of pathogens in mineral soils, where pathogen suppression has been directly correlated with $\mathrm{Al}^{3+}$ activity, a species of $\mathrm{Al}$ considered toxic to plants (13).

Many of the major pathogens that have been suppressed in compost-amended media are sensitive to Al. Members of the phylum Oomycota, including Pythium spp. (19), Phytophthora spp. (1), and Aphanomyces spp. (24), are suppressed by Al, as are $R$. solani (22) and Thielaviopsis basicola (29-32). The potential toxicity of Al to soil microorganisms, including biocontrol agents, limits the integrated use of biotic and abiotic factors for control of plant pathogens. The careful regulation of $\mathrm{Al}$ activity and form in an organic medium, however, may enable the incorporation of multiple mechanisms for disease control into a commercial potting medium as part of a disease management strategy.

The overall goal of this work was to develop a disease-suppressive potting medium by incorporating both biological and abiotic mechanisms of pathogen suppression into a potting medium containing CSW. To accomplish this goal, our objectives were to (i) test the efficacy of CSW-amended medium for biologically mediated suppression of $P$. parasitica var. nicotianae over time, and (ii) determine if $\mathrm{Al}$ amendment of the CSW-amended medium altered biological suppression.

\section{MATERIALS AND METHODS}

Medium preparation. CSW was obtained from the Animal Waste Management Center at North Carolina State University. Swine waste was harvested from a lagoon, combined with woodchips and composted in a sheltered bin. After progressing through two heating cycles, the composted material was cured in an outdoor bin for further decomposition. A mixture of $20 \%$ ( $\mathrm{vol} / \mathrm{vol}$ ) CSW was prepared by mixing the CSW with Fafard No. 2, a soilless potting medium containing Canadian sphagnum peat moss, perlite, and vermiculite plus a wetting agent and nutrients (Fafard, Inc., Agawam, MA). The CSW used in this study is from the same source as the CSW1 previously described as suppressive to R. solani (12).

Inoculum production. A race 0 isolate of $P$. parasitica var. nicotianae was used in all tests. This isolate was obtained from infested soil in Duplin County, NC, and was provided by M. Sullivan, N.C. State University, Raleigh. Cultures were maintained on corn meal agar (CMA) (Difco Laboratories, Detroit). To generate inoculum for experiments, leaf disks (1-cm diameter) were cut from mature vinca plants (Catharanthus roseus) with a cork borer and autoclaved in water plus a drop of Tween 80 (Fisher, Norcross, GA) for $30 \mathrm{~min}$ on two consecutive days. The sterilized leaf disks were placed on CMA around an agar plug of $P$. parasitica var. nicotianae. The pathogen colonized the sterile leaf disks for 4 days at room temperature, and colonized leaf disks were removed from plates for use as inoculum.

Effects of $\mathrm{Al}$ amendment and steaming on sporangia production. Six liters of $20 \% \mathrm{CSW}$ (loose bulk density $\left[D_{b}\right]$ of $0.22 \mathrm{~g} \mathrm{ml}^{-1}$ ) was mixed thoroughly in a plastic bag and divided in half. One half was steamed at $99^{\circ} \mathrm{C}$ for $30 \mathrm{~min}$ on two consecutive days. The second half remained unsteamed. The steamed and unsteamed media were then divided into three aliquots to establish a complete factorial treatment design. The steamed and unsteamed media were amended 1 day after steaming with an $\mathrm{Al}_{2}\left(\mathrm{SO}_{4}\right)_{3}$ solution at either $\mathrm{pH} 4$ or $\mathrm{pH} 6$ at a rate of $0.0079 \mathrm{~g}$ of $\mathrm{Al} \mathrm{g}^{-1}$ of medium. The Al-amendment solutions were prepared by making a $0.05 \mathrm{M} \mathrm{Al}_{2}\left(\mathrm{SO}_{4}\right)_{3}$ solution and adjusting the $\mathrm{pH}$ to either 4 or 6 with the addition of $1 \mathrm{~N} \mathrm{KOH}$. Deionized water was added to the no-Al control treatments so that all treatments contained the same volume of liquid. Each suspension was incubated for $24 \mathrm{~h}$ in a plastic beaker to allow for equilibration of $\mathrm{Al}$ in the media.

The effects of steaming and $\mathrm{Al}$ amendment of $20 \% \mathrm{CSW}$ on production of sporangia were monitored at four time points over a 23-day period. The saturated, treated media were placed into 150-ml fritted-glass Büchner funnels with three replicate funnels for each of the four time points. Amended CSW was packed to an approximate $D_{b}$ of $0.188 \mathrm{~g} \mathrm{~cm}^{-3}$ and then equilibrated at $-2.5 \mathrm{kPa}$ soil matric potential $\left(\Psi_{\mathrm{m}}\right)$ with the use of hanging water columns. The placement of media in funnels was considered day 0. Samples were taken from equilibrated media on day 0 to assess microbial respiration in the medium over a 3 -week period.

Fifteen colonized leaf disks were buried in each of three replicate funnels on days $0,6,13$, and 21 . Leaf disks remained buried for $48 \mathrm{~h}$ in media maintained at $-2.5 \mathrm{kPa} \Psi_{\mathrm{m}}$. After $48 \mathrm{~h}$, disks were retrieved from the media, rinsed with deionized water, and placed on glass slides. The number of sporangia formed on the leaf disk edge observed across a randomly selected $10 \times$ field of view of an inverted light microscope was counted, with two counts made per leaf disk. Sporangium count data were analyzed with the general linear models procedure (PROC GLM), and treatment differences were determined with a Waller-Duncan $k$ ratio test $(k=100)$ (SAS Institute, Cary, NC). After leaf disks were retrieved from funnels, the remaining medium was destructively sampled for measurement of $\mathrm{pH}$ and $\mathrm{KCl}$-exchangeable $\mathrm{Al}$.

Exchangeable $\mathbf{A l}$ and $\mathbf{p H}$ determination. After retrieval of leaf disks on days $2,8,15$, and 23 , the content of each funnel was placed into plastic bags and mixed thoroughly. Two 3-g moist subsamples $(0.85 \mathrm{~g}$ dry weight equivalent) were taken from each bag, placed in glass beakers, and frozen for $\mathrm{pH}$ and $\mathrm{Al}$ analysis. The $\mathrm{pH}$ was determined in a 1:2(wt/vol) suspension of $0.01 \mathrm{M}$ $\mathrm{CaCl}_{2}$ solution. Potassium-exchangeable $\mathrm{Al}$ was determined with a modified acid-base titration procedure (36). Each sample was suspended in $25 \mathrm{ml}$ of a $1 \mathrm{M} \mathrm{KCl}$ solution for $2 \mathrm{~h}$, filtered through Q5 filter paper (Fisher Scientific), and rinsed three times with $25 \mathrm{ml}$ of $1 \mathrm{M} \mathrm{KCl}$. Ten drops of phenolphthalein solution were added to each extract, and extracts were titrated with $0.1 \mathrm{M}$ $\mathrm{NaOH}$ to a pale pink endpoint. A drop of $0.1 \mathrm{M} \mathrm{HCl}$ was added to turn the solution colorless, and then $10 \mathrm{ml}$ of $4 \%$ (wt/vol) $\mathrm{NaF}$ was added. In the presence of $\mathrm{Al}$, a stable fluoroaluminate complex forms and the pink color returns. Extracts were then titrated to a clear endpoint with the addition of $0.1 \mathrm{M} \mathrm{HCl}$. Three moles of $\mathrm{H}^{+}$will titrate 1 mole of exchangeable $\mathrm{Al}$.

Microbial activity. Upon the establishment and equilibration of funnels on day 0 , a $5.0 \mathrm{~g}$ dry weight equivalent was removed from each funnel to monitor basal microbial respiration rates in the various treatments. Microbial activity was assessed using an incubation technique (37) that measures evolution of $\mathrm{CO}_{2}$ over a 3 -week period. The 5.0-g subsamples were placed in plastic beakers and each beaker was set in the bottom of a sealed 2-liter Mason jar. Fifty-milliliter glass beakers, suspended in Mason jars, were used to trap $\mathrm{CO}_{2}$ in $5 \mathrm{ml}$ of $0.5 \mathrm{~N} \mathrm{NaOH}$. Two jars containing $\mathrm{NaOH}$ solution were set up in the absence of medium as "no 
respiration" controls. Mason jars were incubated at room temperature. On days $1,7,14$, and 22 , glass beakers were removed from Mason jars and beakers containing fresh $0.5 \mathrm{~N} \mathrm{NaOH}$ were replaced in Mason jars. Carbonate was precipitated from the $\mathrm{NaOH}$ solutions with the addition of $5 \mathrm{ml}$ of $0.5 \mathrm{M} \mathrm{BaCl}_{2}$, and then 2 drops of phenolphthalein were added to each beaker. The residual base (unconsumed by trapping of $\mathrm{CO}_{2}$ ) was titrated with $0.1 \mathrm{~N} \mathrm{HCl}$ to a clear endpoint to indirectly assess $\mathrm{CO}_{2}$ evolution. Respiration rates were calculated as milligrams of $\mathrm{CO}_{2}$ per gram of medium per day.

Effects of $\mathrm{Al}$ amendment and steaming on pathogen populations. The effects of steaming and $\mathrm{Al}$ amendment of $20 \% \mathrm{CSW}$ on pathogen populations were monitored at four time points over a period of 23 days. Although similar in design to the experiment focusing on sporangium production, this experiment contained only two factors of $\mathrm{Al}$ amendment: no $\mathrm{Al}$ control and $\mathrm{pH} 4$ amendment solution at a rate of $0.0079 \mathrm{~g}$ of $\mathrm{Al} \mathrm{g}^{-1}$ of medium. Steaming and $\mathrm{Al}$ amendment followed the same methodology as in the sporangium production experiment. A complete factorial treatment design with three replicate funnels of each of four treatments was used at each of four time points. After funnels were set up and equilibrated at $-2.5 \mathrm{kPa} \Psi_{\mathrm{m}}$ on day 0 , one infested leaf disk was placed at approximately a $0.5 \mathrm{~cm}$ depth in each funnel. Funnels for subsequent time points were infested on days 6, 13, and 21. Leaf disks remained in funnels for $24 \mathrm{~h}$ before the water potential was raised to $0 \mathrm{kPa}$ with respect to the surface of the media to induce zoospore release (26). Funnels remained flooded for $12 \mathrm{~h}$ and were reequilibrated at $-2.5 \mathrm{kPa}$ for approximately $10 \mathrm{~h}$. Media were destructively sampled on days $2,8,15$, and 23 to determine pathogen population, $\mathrm{pH}$, and $\mathrm{K}$-exchangeable $\mathrm{Al}$. Furthermore, in the first two runs of the experiment, the type of propagule giving rise to assayed colonies was determined microscopically on day 2.

Pathogen population was determined using an assay on a Phytophthora-selective agar medium (PARP) (21) containing $50 \mu \mathrm{g}$ of hymexazol (Sankyo Co., Tokyo) $\mathrm{ml}^{-1}$. The contents of each funnel were placed into plastic bags and mixed thoroughly. Three 1-g moist samples were taken from each funnel and suspended in $50 \mathrm{ml}$ of deionized water. Each suspension was spread over 10 petri plates of PARP medium and incubated for 2 days in the dark. Plates were rinsed with water and colonies of $P$. parasitica var. nicotianae were counted. Population data analysis, $\mathrm{pH}$, and $\mathrm{K}$-exchangeable $\mathrm{Al}$ measurements were all completed using the aforementioned techniques and procedures.

The type of propagule giving rise to colonies of $P$. parasitica var. nicotianae in the assay was determined by spreading a 3-g suspension of medium from each of four treatments in $50 \mathrm{ml}$ of water over 10 plates of PARP. After $18 \mathrm{~h}$, the particulates were gently rinsed off the plates with tap water and colonies were observed under an inverted light microscope. Ten colonies were selected at random and the propagule-type giving rise to a germ tube was noted.

In the second run of the population experiment, the number of sporangia produced on infested leaf disks buried for $24 \mathrm{~h}$ before flooding was also assessed. An additional funnel for each of four treatments was set up for each of four time points. Fifteen infested leaf disks were buried in each funnel on days $0,6,13$, and 21. After $24 \mathrm{~h}$, leaf disks were retrieved from the media and the number of sporangia produced was assessed using the same technique as in the sporangium production experiment. Sporangia were counted at times corresponding to the concurrent flooding of population experimental funnels.

Soil moisture characteristic. Saturated $20 \%$ CSW medium was placed into 15 Büchner funnels and packed to a $D_{b}$ of approximately $0.18 \mathrm{~g} \mathrm{~cm}^{-3}$. Plastic bags were placed over each funnel and funnels were brought to saturation for $24 \mathrm{~h}$. Media were allowed to equilibrate at $0,-1.0,-2.5,-5.0$, and $-10.0 \mathrm{kPa}$ $\Psi_{\mathrm{m}}$ for $24 \mathrm{~h}$ with respect to the medium surface, with three replicate funnels at each $\Psi_{\mathrm{m}}$. One sample removed from each funnel was weighed and oven dried at $105^{\circ} \mathrm{C}$ for $48 \mathrm{~h}$ to determine dry weights. Volumetric water content was averaged across the three replicate samples.

\section{RESULTS}

Effects of Al amendment and steaming on sporangium production. Steaming and amendment with $\mathrm{Al}$ affected the number of sporangia produced on infested leaf disks that had been buried for $48 \mathrm{~h}$ (Table 1). Statistical analyses comparing treatments were only conducted within each time point. Sporangium production data from different runs of the experiment could not be combined. However, similar trends were observed in both experimental runs. Amendment with the $\mathrm{pH} 4 \mathrm{Al}_{2}\left(\mathrm{SO}_{4}\right)_{3}$ solution consistently reduced sporangium production on day 2. The $\mathrm{pH} 6$ amendment solution did not inhibit sporangium production throughout the 3 -week period. Amendment with the $\mathrm{pH} 4 \mathrm{Al}_{2}\left(\mathrm{SO}_{4}\right)_{3}$ solution reduced sporangium production at day 2 by approximately $50 \%$ in steamed medium in both experimental runs (Table 1). The same $\mathrm{Al}$ amendment of unsteamed medium resulted in a 64 and $38 \%$ reduction of sporangium production at day 2 for runs 1 and 2, respectively (Table 1). In the first run of the experiment, the $\mathrm{Al}$ effect was only observed on day 2 . In the second run, however, the $\mathrm{Al}$ effect extended to days 8 and 15 (Table 1).

Steamed media consistently resulted in higher numbers of sporangia produced on days 8,15 , and 23 than in the corresponding unsteamed media (Table 1). A steaming effect was not observed

TABLE 1. Average number of sporangia ${ }^{\mathrm{w}}$ of Phytophthora parasitica var. nicotianae produced on edges of infested leaf disks buried for $48 \mathrm{~h}$ in steamed ${ }^{\mathrm{x}}$ and unsteamed potting medium amended with $\mathrm{pH} 4$ or $\mathrm{pH} 6 \mathrm{Al}_{2}\left(\mathrm{SO}_{4}\right)_{3}$ solutions ${ }^{\mathrm{y}}$

\begin{tabular}{|c|c|c|c|c|c|c|c|}
\hline & Steamed control & $\begin{array}{l}\text { Not steamed } \\
\text { control }\end{array}$ & Steamed pH 4 & $\begin{array}{l}\text { Not steamed } \\
\text { pH } 4\end{array}$ & Steamed pH 6 & $\begin{array}{l}\text { Not steamed } \\
\text { pH6 }\end{array}$ & $\begin{array}{l}\text { Significant factors } \\
\quad(P \leq 0.05)\end{array}$ \\
\hline \multicolumn{8}{|l|}{ Run 1} \\
\hline Day 2 & $26 \mathrm{a}^{\mathrm{z}}$ & $19 \mathrm{a}-\mathrm{c}$ & $14 \mathrm{~cd}$ & $7 \mathrm{~d}$ & $22 \mathrm{ab}$ & $18 \mathrm{bc}$ & $\mathrm{Al}$ \\
\hline Day 15 & $28 \mathrm{a}$ & $9 \mathrm{~b}$ & $26 \mathrm{a}$ & $8 \mathrm{~b}$ & $27 \mathrm{a}$ & $8 \mathrm{~b}$ & Steam \\
\hline Day 23 & $23 \mathrm{a}$ & $11 \mathrm{c}$ & $22 \mathrm{a}$ & $17 \mathrm{~b}$ & $24 \mathrm{a}$ & $12 \mathrm{c}$ & Steam \\
\hline \multicolumn{8}{|l|}{ Run 2} \\
\hline Day 2 & $9.8 \mathrm{~b}$ & $6.6 \mathrm{~b}$ & $4.4 \mathrm{c}$ & $4.1 \mathrm{c}$ & $17.8 \mathrm{a}$ & $16 \mathrm{a}$ & $\mathrm{Al}$ \\
\hline Day 23 & $5.9 \mathrm{a}$ & $0.8 \mathrm{~b}$ & $4.7 \mathrm{a}$ & $1.2 \mathrm{~b}$ & $5.0 \mathrm{a}$ & $1.1 \mathrm{~b}$ & Steam \\
\hline
\end{tabular}

${ }^{w}$ Sporangia were counted on infested leaf disks buried for $48 \mathrm{~h}$. The number of sporangia produced per $1.2 \mathrm{~mm}$ of leaf disk edge was ascertained by counting those across a $10 \times$ field of view under a light microscope.

${ }^{x}$ Steamed $30 \mathrm{~min}$ at $98.6^{\circ} \mathrm{C}$ on two consecutive days.

${ }^{\mathrm{y}}$ Medium was amended with $0.0079 \mathrm{~g}$ of $\mathrm{Al} \mathrm{g}^{-1}$ of medium as a $0.05 \mathrm{M} \mathrm{Al}_{2}\left(\mathrm{SO}_{4}\right)_{3}$ solution adjusted with $1.0 \mathrm{~N} \mathrm{KOH}$ to either $\mathrm{pH} 4$ or $\mathrm{pH} 6$.

${ }^{\mathrm{z}}$ Values followed by different letters within a row indicate significant differences $(P \leq 0.05)$. 
on day 2. In the first run of the experiment, steaming resulted in $50 \%$ more sporangia produced in the media unamended with $\mathrm{Al}$ and in the $\mathrm{pH} 6 \mathrm{Al}$ amendment on day 23 than in the media amended with the $\mathrm{pH} 4 \mathrm{Al}$ amendment (Table 1). The $\mathrm{pH} 4 \mathrm{Al}$ amendment resulted in a $24 \%$ reduction in sporangium production in the unsteamed media on day 23 (Table 1). In the second run of the experiment, sporangium production on day 23 was reduced by greater than $75 \%$ in all unsteamed treatments (Table 1). Although steaming and $\mathrm{Al}$ amendments were both statistically significant factors in the reduction of sporangia production at various time points, no significant interaction of these main effects was observed.

Amendment with $\mathrm{Al}$ altered the $\mathrm{pH}$ of the media. Unamended media had a $\mathrm{pH}$ of approximately 5.7 over the 3-week period
(Fig. 1). Little difference in $\mathrm{pH}$ was observed between steamed and unsteamed media (Fig. 1). Amendment with the $\mathrm{Al}_{2}\left(\mathrm{SO}_{4}\right)_{3}$ solution at $\mathrm{pH} 4$ resulted in a lower $\mathrm{pH}$; however, the $\mathrm{pH}$ tended to increase over the 3-week period. For example, in the first run of the experiment, the $\mathrm{pH}$ of the $\mathrm{pH} 4 \mathrm{Al}$-amended media was approximately 5.2 on day 2 and 5.6 on day 23 (Fig. 1A). The pH 6 $\mathrm{Al}$-amended media had a higher $\mathrm{pH}$ than the unamended control and the $\mathrm{pH}$ also increased from approximately 6.0 to 6.3 over time from day 0 to 23 (Fig. 1).

Amendment of the CSW mix with the $\mathrm{pH} 4$ solution resulted in higher concentrations of $\mathrm{K}$-exchangeable $\mathrm{Al}$ than in the $\mathrm{pH} 6 \mathrm{Al}-$ amended media. Amendment with the $\mathrm{pH} 4 \mathrm{Al}_{2}\left(\mathrm{SO}_{4}\right)_{3}$ solution resulted in initial extractable $\mathrm{Al}$ concentrations ranging from 3 to $7 \mu \mathrm{M} \mathrm{Al} \mathrm{g} \mathrm{g}^{-1}$ of medium across runs and steam versus unsteamed
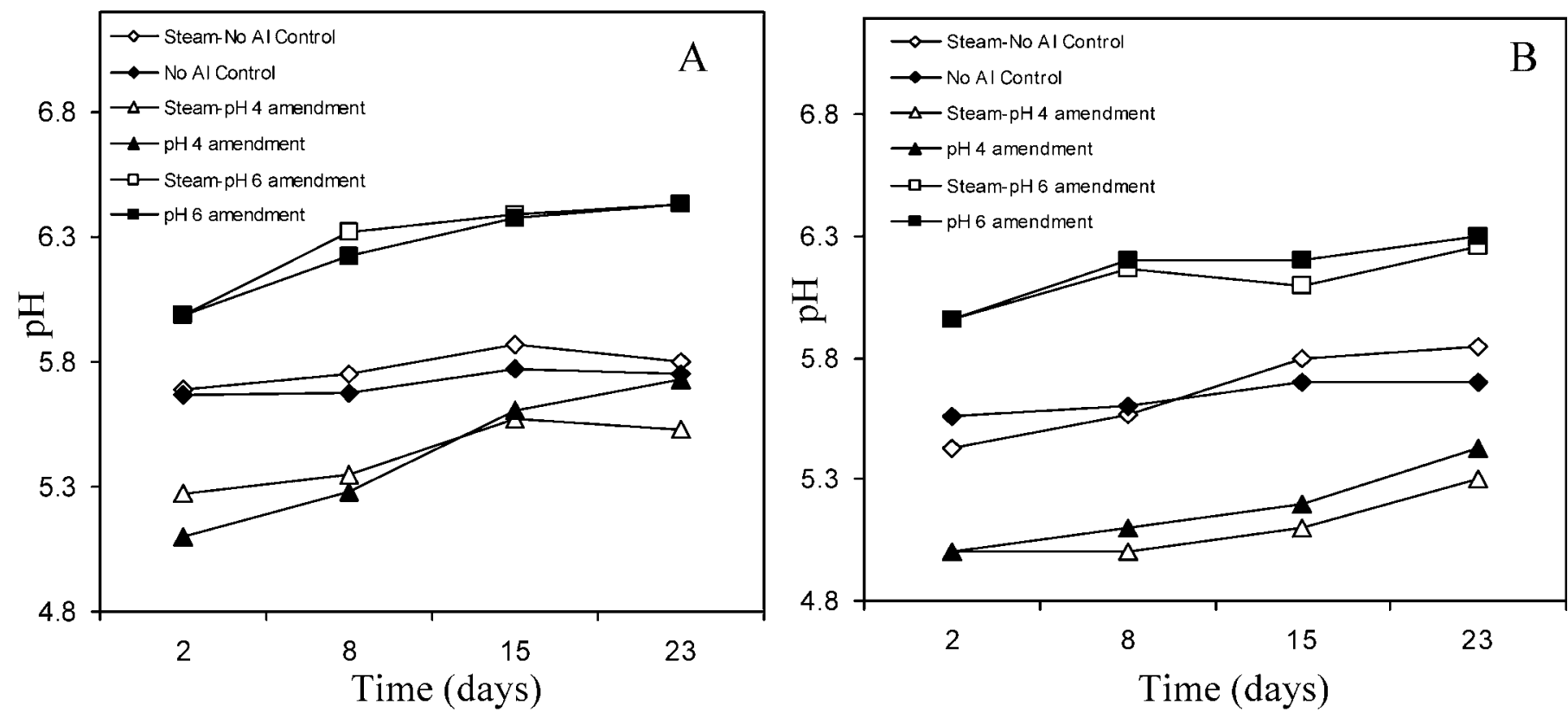

Fig. 1. Trends in $\mathrm{pH}$ of steamed and unsteamed media amended with $\mathrm{pH} 4$ or $\mathrm{pH} 6 \mathrm{Al}_{2}\left(\mathrm{SO}_{4}\right)_{3}$ solutions. Samples were taken from media containing infested leaf disks that were buried for 48 -h intervals and then removed at each time point to assess sporangium production. $\mathbf{A}$ and $\mathbf{B}$ represent separate repetitions of the experiment.
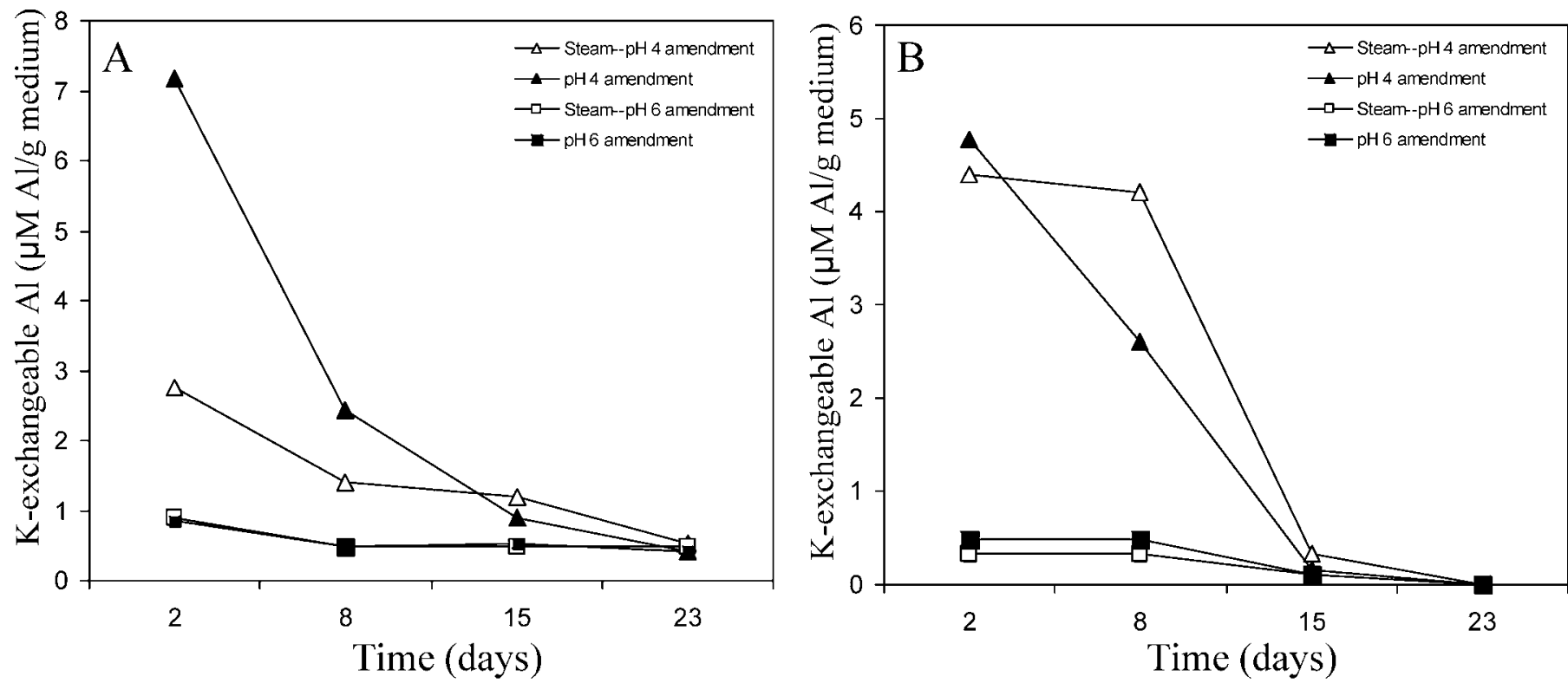

Fig. 2. K-exchangeable $\mathrm{Al}$ in steamed and unsteamed media amended with $\mathrm{pH} 4$ or $\mathrm{pH} 6 \mathrm{Al}_{2}\left(\mathrm{SO}_{4}\right)_{3}$ solutions. Samples were taken from media containing infested leaf disks that were buried for 48 -h intervals and then removed at each time point to assess sporangium production. A and $\mathbf{B}$ represent separate repetitions of the experiment. 
media (Fig. 2). In these treatments, $\mathrm{Al}$ concentrations tended to decrease over time, equilibrating at approximately 0.5 and $0 \mu \mathrm{M}$ $\mathrm{Al} \mathrm{g}{ }^{-1}$ of media on day 23 in runs 1 and 2, respectively (Fig. 2). The $\mathrm{pH} 6$ amendment resulted in less than $1 \mu \mathrm{M} \mathrm{Al} \mathrm{g} \mathrm{g}^{-1}$ of medium on day 2 , and 0.5 and $0 \mu \mathrm{M} \mathrm{Al} \mathrm{g}^{-1}$ of medium on day 23 in runs 1 and 2, respectively (Fig. 2).

Microbial respiration ranged between 0.2 and $0.6 \mathrm{mg}$ of $\mathrm{CO}_{2} \mathrm{~g}^{-1}$ of medium day ${ }^{-1}$ during days 7 to 22 over both runs of the experiment (Fig. 3). In run 1, however, peak respiration was recorded on day 1 with a rate of $1.6 \mathrm{mg}$ of $\mathrm{CO}_{2} \mathrm{~g}^{-1}$ day $^{-1}$ (Fig. 3A). Furthermore, the steamed media exhibited consistently higher respiration rates than that of the corresponding unsteamed media on day 1 in the first experimental run (Fig. 3A).

Effects of $\mathrm{Al}$ amendment and steaming on pathogen populations. Both $\mathrm{Al}$ and steaming affected pathogen populations on leaf disks buried for $24 \mathrm{~h}$ prior to flooding. Although population data were more variable than sporangium production data, Al significantly reduced pathogen populations on day 2 in run 1 and on days 2 and 15 in run 2 (Table 2). At each of these points, pathogen populations were reduced by at least $50 \%$ compared with that of the corresponding unamended control. Percent population reduction varied from 52 to $99 \%$ at these time points. Furthermore, all of the colonies assayed from the treated media were derived from encysted zoospores.

Steaming had an inconsistent effect on pathogen populations in run 1 , evidenced by increased pathogen populations in steamtreated medium on day 2 and the subsequent decrease in populations in steam-treated medium on day 8 (Table 2). These steam effects, however, were only observed in the unamended (no Al control) treatments. Because steaming had a consistent effect on sporangium production after infested leaf disks were buried for $48 \mathrm{~h}$, the number of sporangia produced at the time of flooding $(24 \mathrm{~h})$ was assessed in the second run of the experiment. The number of sporangia produced on leaf disks buried $24 \mathrm{~h}$ (time of flooding) was only affected by the steam treatment on day 22 (Table 3). In this system, Al reduced sporangia production on days 1,7 , and 14 by 40 to $95 \%$ (Table 3 ), and K-exchangeable $\mathrm{Al}$ concentrations remained above $2 \mu \mathrm{M} \mathrm{Al} \mathrm{g}{ }^{-1}$ at the time points corresponding to this suppression (Fig. 4). Similar to the sporangium production experiments, no interaction of $\mathrm{Al}$ amendment and steaming was observed in the pathogen population study.

In the population experiments, the $\mathrm{pH}$ trends were similar to those in the sporangia production experiments (Fig. 5). The K-exchangeable $\mathrm{Al}$ concentrations ranged between 5 and $9 \mu \mathrm{M} \mathrm{Al} \mathrm{g}{ }^{-1}$ on day 2, but equilibrated down to concentrations ranging from approximately 1 to $5 \mu \mathrm{M} \mathrm{Al} \mathrm{g}^{-1}$ at day 23 (Fig. 4). After 3 weeks of incubation, the flooded media in the population study equilibrated at higher concentrations of $\mathrm{Al}$ than the corresponding unflooded treatments in the sporangia production experiment (Figs. 2 and 4). Furthermore, in both experiments, concentrations of Kexchangeable $\mathrm{Al}$ in the steamed medium tended to be lower than those in the corresponding unsteamed medium over much of the 3-week period (Figs. 2 and 4).

A soil moisture characteristic was generated between 0 and $-10 \mathrm{kPa} \Psi_{\mathrm{m}}$. The percent water-filled pore space at $0,-0.1,-2.5$, -5.0 , and $-10.0 \mathrm{kPa} \Psi_{\mathrm{m}}$ were $100,80,47,44$, and $27 \%$, respectively.

\section{DISCUSSION}

Both abiotic and biological factors suppressive to $P$. parasitica var. nicotianae were incorporated into an organic potting medium containing $20 \% \mathrm{CSW}$ and an $\mathrm{Al}$ amendment. Amendment of the medium with a pH $4 \mathrm{Al}_{2}\left(\mathrm{SO}_{4}\right)_{3}$ solution consistently inhibited sporangium production on day 2 , whereas the $\mathrm{pH} 6$ amendment

TABLE 2. Average number of propagules ${ }^{\mathrm{w}}$ of Phytophthora parasitica var. nicotianae in steamed ${ }^{\mathrm{x}}$ and unsteamed potting media amended with a $\mathrm{pH} 4$ $\mathrm{Al}_{2}\left(\mathrm{SO}_{4}\right)_{3}$ solution ${ }^{\mathrm{y}}$

\begin{tabular}{|c|c|c|c|c|c|}
\hline & $\begin{array}{c}\text { Steamed } \\
\text { control }\end{array}$ & $\begin{array}{c}\text { Not } \\
\text { steamed } \\
\text { control }\end{array}$ & $\begin{array}{c}\text { Steamed } \\
\mathrm{pH} 4\end{array}$ & $\begin{array}{c}\text { Not } \\
\text { steamed } \\
\text { pH } 4\end{array}$ & $\begin{array}{l}\text { Significan } \\
\text { factors } \\
(P \leq 0.05)\end{array}$ \\
\hline \multicolumn{6}{|l|}{ Run 1} \\
\hline Day 2 & $133.6 \mathrm{a}^{\mathrm{z}}$ & $74.4 \mathrm{~b}$ & $27.6 \mathrm{c}$ & $6.8 \mathrm{c}$ & Steam; Al \\
\hline Day 8 & $150.0 \mathrm{~b}$ & $354.6 \mathrm{a}$ & $72.6 \mathrm{~b}$ & $183.9 \mathrm{ab}$ & Steam \\
\hline Day 15 & $159.4 \mathrm{a}$ & $130.2 \mathrm{a}$ & $21.5 \mathrm{a}$ & $124.4 \mathrm{a}$ & - \\
\hline Day 23 & $139.4 \mathrm{ab}$ & $464.6 \mathrm{a}$ & $10.2 \mathrm{~b}$ & $5.3 \mathrm{~b}$ & - \\
\hline \multicolumn{6}{|l|}{ Run 2} \\
\hline Day 2 & $275.3 \mathrm{ab}$ & $325.2 \mathrm{a}$ & $41.1 \mathrm{~b}$ & $27.2 \mathrm{~b}$ & $\mathrm{Al}$ \\
\hline Day 8 & $90.6 \mathrm{a}$ & $75.6 \mathrm{a}$ & $45.7 \mathrm{a}$ & $58.8 \mathrm{a}$ & - \\
\hline Day 15 & $11.2 \mathrm{a}$ & $6.7 \mathrm{ab}$ & $0.1 \mathrm{~b}$ & $3.2 \mathrm{~b}$ & $\mathrm{Al}$ \\
\hline Day 23 & $10.2 \mathrm{a}$ & $5.0 \mathrm{a}$ & $0.7 \mathrm{a}$ & $6.3 \mathrm{a}$ & - \\
\hline
\end{tabular}

${ }^{w}$ Pathogen populations were assessed after infested leaf disks were buried for $24 \mathrm{~h}$, media were flooded for $12 \mathrm{~h}$, and reequilibrated at $25 \mathrm{~cm}$ soil moisture tension for $12 \mathrm{~h}$.

x Steamed for $30 \mathrm{~min}$ at $98.6^{\circ} \mathrm{C}$ on two consecutive days.

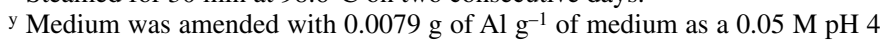
$\mathrm{Al}_{2}\left(\mathrm{SO}_{4}\right)_{3}$ solution.

${ }^{z}$ Different letters across rows designate significant differences based on the Waller-Duncan $k$ ratio test $(k=100)$.
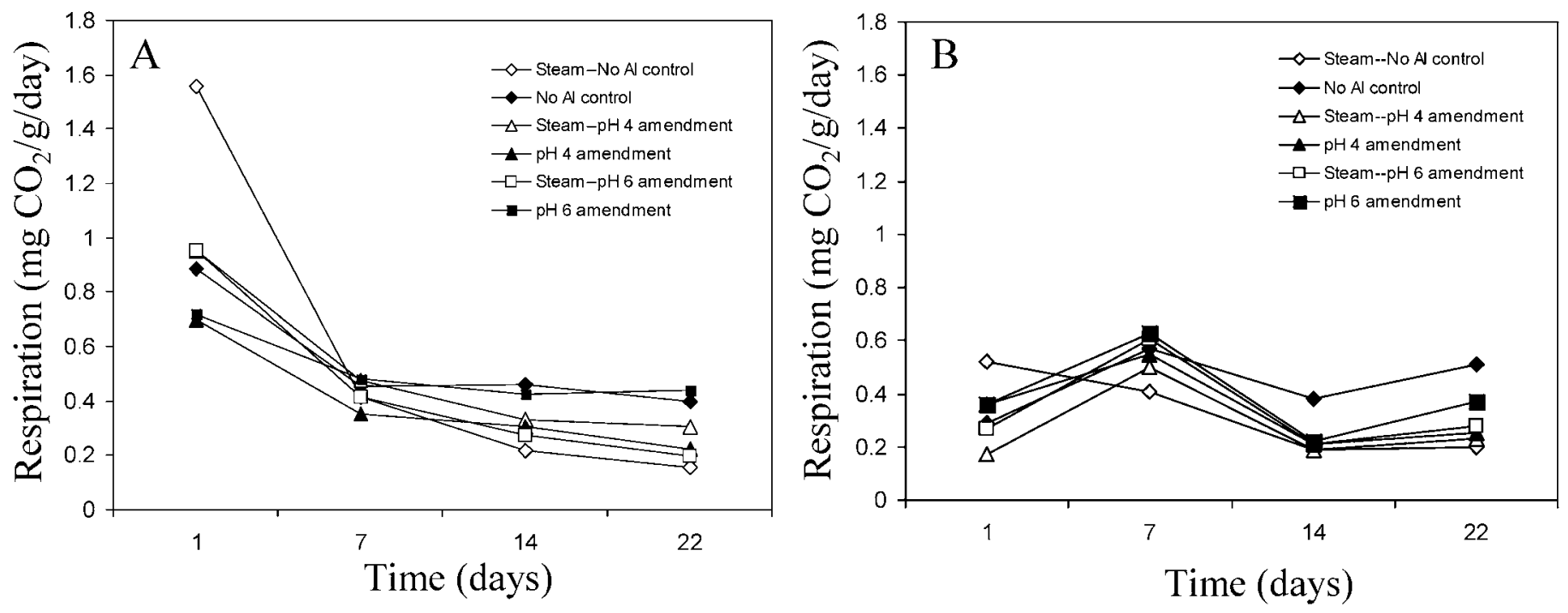

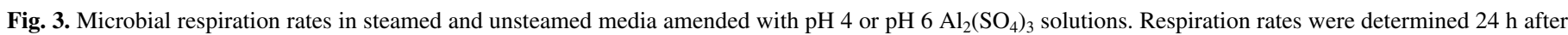
infested leaf disks were buried in corresponding media for 48 h. A and $\mathbf{B}$ represent separate repetitions of the experiment. 
was ineffective. The differential effect of the two amendment solutions may be related to the heightened overall concentration of K-exchangeable $\mathrm{Al}$ in the $\mathrm{pH} 4$ amendment $\left(>3 \mu \mathrm{M} \mathrm{g}^{-1}\right)$ compared with that of the $\mathrm{pH} 6$ amendment $\left(<1 \mu \mathrm{M} \mathrm{g}^{-1}\right)$. Similar amendment of peat with $\mathrm{Al}_{2}\left(\mathrm{SO}_{4}\right)_{3}$ solution at $\mathrm{pH} 6$ consistently suppressed populations of $P$. parasitica var. nicotianae at $\mathrm{K}$-exchangeable $\mathrm{Al}$ concentrations at $1 \mu \mathrm{M} \mathrm{g}^{-1}$ of peat (13); however, the initial peat amendment contained twice the level of $\mathrm{Al}$ used in the present study.

The lower concentration of K-exchangeable Al in 20\% CSW amended with the pH 6 amendment solution is likely related to three interrelated, $\mathrm{pH}$-dependent phenomena: (i) lower activity of $\mathrm{Al}$ in the amendment solution, (ii) heightened affinity of organic matter for $\mathrm{Al}$, and (iii) stronger affinity of hydrolyzed $\mathrm{Al}$ ions for charged groups on the organic matter. The $\mathrm{pH} 6$ amendment solution has a lower activity of $\mathrm{Al}$ in solution than the $\mathrm{pH} 4$ amendment solution due to the $\mathrm{pH}$-dependent formation of an $\mathrm{Al}(\mathrm{OH})_{3}$ precipitate. In these respective $\mathrm{pH} 4$ and $\mathrm{pH} 6$ amendment solutions, the total amount of soluble $\mathrm{Al}$ with respect of gibbsite would be $10^{-3}$ and $10^{-6.3} \mathrm{M}$ (28); however, the precipitate may also have been a more soluble Al-bearing mineral. The higher $\mathrm{pH}$ (6.0 to 6.4) of the medium amended with the $\mathrm{pH} 6$ amendment

TABLE 3. Average number of sporangia ${ }^{\mathrm{w}}$ of Phytophthora parasitica var. nicotianae produced on the edge of infested leaf disks buried for $24 \mathrm{~h}$ in steamed ${ }^{\mathrm{x}}$ and unsteamed potting media amended with a $\mathrm{pH} 4 \mathrm{Al}_{2}\left(\mathrm{SO}_{4}\right)_{3}$ solution $^{\mathrm{y}}$

\begin{tabular}{lccccc}
\hline Run 2 & $\begin{array}{c}\text { Steamed } \\
\text { control }\end{array}$ & $\begin{array}{c}\text { Not } \\
\text { steamed } \\
\text { control }\end{array}$ & $\begin{array}{c}\text { Steamed } \\
\mathrm{pH} \mathrm{4}\end{array}$ & $\begin{array}{c}\text { Not } \\
\text { steamed } \\
\mathrm{pH} 4\end{array}$ & $\begin{array}{c}\text { Significant } \\
\text { factors } \\
(P \leq 0.05)\end{array}$ \\
\hline Day 1 & $19 \mathrm{a}^{\mathrm{z}}$ & $20 \mathrm{a}$ & $4 \mathrm{~b}$ & $1 \mathrm{~b}$ & $\mathrm{Al}$ \\
Day 7 & $10 \mathrm{a}$ & $8 \mathrm{ab}$ & $5 \mathrm{bc}$ & $2 \mathrm{c}$ & $\mathrm{Al}$ \\
Day 14 & $20 \mathrm{a}$ & $14 \mathrm{ab}$ & $12 \mathrm{~b}$ & $13 \mathrm{~b}$ & $\mathrm{Al}$ \\
Day 22 & $17 \mathrm{a}$ & $6 \mathrm{~b}$ & $17 \mathrm{a}$ & $4 \mathrm{~b}$ & Steam \\
\hline
\end{tabular}

${ }^{\mathrm{w}}$ Sporangia were counted on infested leaf disks buried for $48 \mathrm{~h}$. The number of sporangia produced per $1.2 \mathrm{~mm}$ of leaf disk edge was ascertained by counting those across a $\times 10$ field of view under a microscope.

${ }^{x}$ Steamed for $30 \mathrm{~min}$ at $98.6^{\circ} \mathrm{C}$ on two consecutive days.

${ }^{\mathrm{y}}$ Medium was amended with $0.0079 \mathrm{~g}$ of $\mathrm{Al} \mathrm{g}^{-1}$ of medium as a $0.05 \mathrm{M} \mathrm{pH} 4$ $\mathrm{Al}_{2}\left(\mathrm{SO}_{4}\right)_{3}$ solution.

${ }^{z}$ Values followed by different letters within a row indicate significant differences $(P \leq 0.05)$.

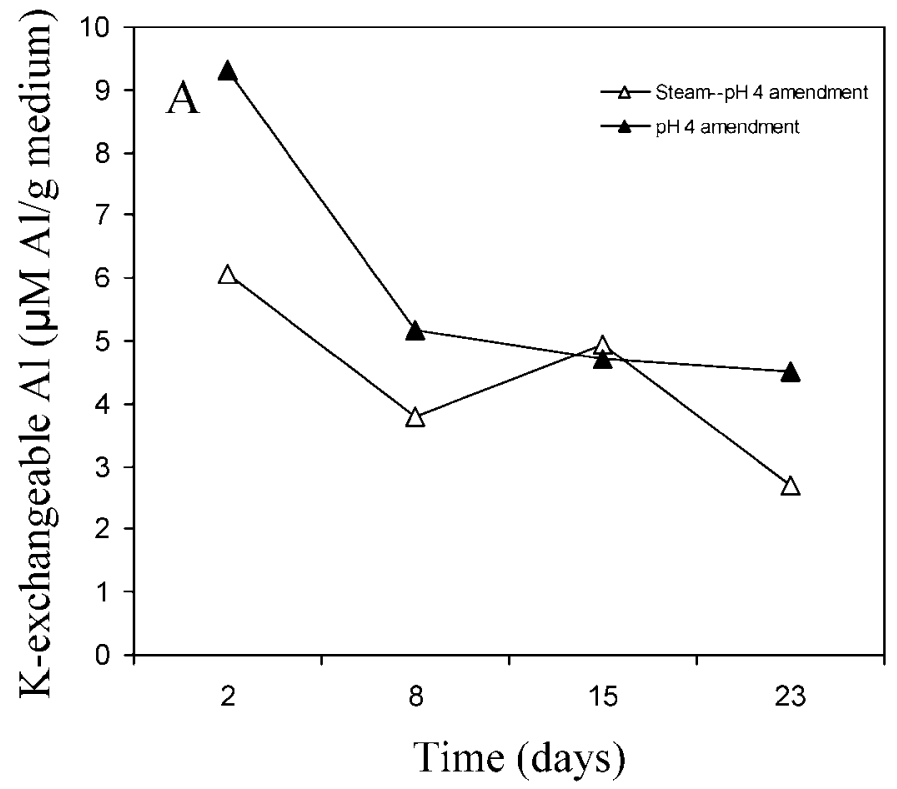

compared with the $\mathrm{pH} 4$ amendment (5.1 to 5.7), increases the affinity of the organic matter for Al by increasing the surface charge of the medium. Furthermore, the distribution of monomeric $\mathrm{Al}$ species differs in each amendment solution, with the $\mathrm{pH} 6$ solution containing a higher proportion of the $\mathrm{Al}(\mathrm{OH})_{2}{ }^{+}$ion (28). This monovalent hydrolysis species forms stronger complexes with charged organic functional groups than the free ionic $\mathrm{Al}^{3+}$ (5) that dominates in the $\mathrm{pH} 4$ amendment solution (28).

In the experiments pertaining to sporangia production and pathogen populations, the concentrations of K-exchangeable $\mathrm{Al}$ decreased over time. Over both runs of the sporangia production experiment, the $\mathrm{K}$-exchangeable $\mathrm{Al}$ concentrations of each treatment equilibrated to the same point on day 23. Because media amended with the two amendment solutions equilibrate at different $\mathrm{pH}$ values, this suggests that $\mathrm{Al}$ activity in solution was maintained in equilibrium with respect to organic matter and not $\mathrm{pH}$. In systems at equilibrium, $\mathrm{Al}$ activity is always governed by the process maintaining the lowest activity of $\mathrm{Al}^{3+}$ in solution.

The $\mathrm{pH}$ in Al-amended media increased by approximately a half of a unit between days 2 and 23. This increase in $\mathrm{pH}$ may be attributed to a loss of $\mathrm{Al}$ from solution. However, the fate of $\mathrm{Al}$ in the system is unknown. Aside from losses of $\mathrm{Al}$ due to precipitation and complexation, other interactions of $\mathrm{Al}$ with the pathogen and the microbial community are possible. For example, it is not known whether the pathogen or other microorganisms accumulated $\mathrm{Al}$ or produced organic acids to complex and sequester the metal.

Al-mediated inhibition of sporangium production was mainly observed early after the amendment. However, Al continued to affect pathogen populations up to 23 days after amendment. Although pathogen population data were more variable than sporangia counts, the prolonged effect of $\mathrm{Al}$ on pathogen populations may have been related to the heightened concentrations of K-exchangeable $\mathrm{Al}$ at these time points. Al-mediated suppression of pathogen populations always occurred at K-exchangeable $\mathrm{Al}$ concentrations above $2 \mu \mathrm{M} \mathrm{Al} \mathrm{g}$ of medium. The media assayed for pathogen populations were flooded for $12 \mathrm{~h}$ to induce zoospore release from sporangia. Consequently, these funnels exhibited higher concentrations of K-exchangeable $\mathrm{Al}$ on day 23 than the corresponding unflooded media used in the sporangium production experiment. Aluminum reduced sporangia production through

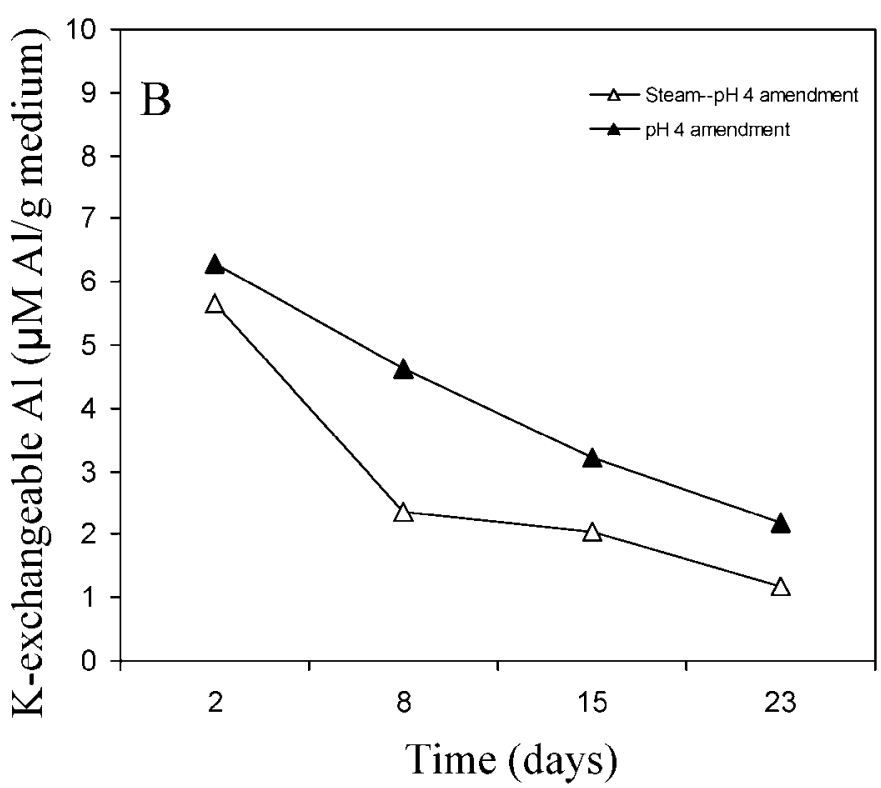

Fig. 4. K-exchangeable $\mathrm{Al}$ in steamed and unsteamed $20 \%$ composted swine waste medium amended with a $0.05 \mathrm{M} \mathrm{Al}_{2}\left(\mathrm{SO}_{4}\right)_{3}$ solution at pH 4 . Samples were taken from funnels containing infested leaf disks that were buried for $24 \mathrm{~h}$ before funnels were flooded. A and $\mathbf{B}$ represent separate repetitions of the experiment. 
day 15 in run 2 of the population experiment. Interestingly, the suppressive medium contained $>2 \mu \mathrm{M} \mathrm{Al} \mathrm{g}$ ' through day 15 in run 2 . Thus, the threshold for $\mathrm{Al}$ toxicity to $P$. parasitica var. nicotianae in organic media may be in the range of $2 \mu \mathrm{M} \mathrm{Al} \mathrm{g}^{-1}$ of medium. The effect of fluctuating water potential on $\mathrm{Al}$ availability in the system has not been directly addressed. The results of these studies, however, suggest that a periodic increase in the water potential of the system may prolong the Al-mediated suppression of $P$. parasitica var. nicotianae.

In the compost medium, Al-mediated inhibition of sporangia production was directly observed by retrieval and observation of infested leaf disks. Although zoospores were the only type of propagule giving rise to colonies assayed from the treated media, we did not determine whether $\mathrm{Al}$ was directly toxic to zoospores. In the second run of the population experiment, it was determined that $\mathrm{Al}$ reduced the number of sporangia produced on leaf disks buried $24 \mathrm{~h}$ prior to flooding (Table 3). Consequently, the noted $\mathrm{Al}$ affect on pathogen populations may be the result of suppression of sporangium production as well as a direct toxicity to zoospore production or viability.

The effect of steaming on the ability of P. parasitica var. nicotianae to produce sporangia suggests that the CSW-amended medium incites a biologically mediated suppression. The timesensitivity of the steam effect on sporangium production suggests that beneficial microbial populations were not active initially in the $20 \% \mathrm{CSW}$ medium. The burst of respiration in the steamed medium on day 1 (no Al control) in the first run of the sporangium production experiment suggests a possible initial burst of activity of endospore-forming bacteria. Diab et al. (12) had noted high populations of these organisms in the CSW-amended medium. Biologically mediated suppression of $P$. parasitica var. nicotianae was consistently observed on days 8,15 , and 23 . Although microbial communities in natural soils may be sensitive to $\mathrm{Al}$ (20), the lack of a steam effect on day 2 in medium that was not amended with $\mathrm{Al}$ suggests that $\mathrm{Al}$ is not the only factor limiting beneficial microbial activity. Beneficial microorganisms may require time to reach threshold population densities in order to exact pathogen suppression, as was suggested earlier for other compost-amended media (8). Because total microbial activity, as estimated by respiration rate, does not correlate with suppression, it is possible that particular populations of organisms are responsible for suppression of $P$. parasitica var. nicotianae in this system. It is also possible that the initial concentrations of free nutrients in the medium were too high to induce microbiostasis early after potting, a phenomenon established by Chen et al. (8) for suppression of populations of Pythium ultimum in compost-amended media.

Diab et al. (12) documented that this CSW-amended medium suppressed damping-off of impatiens caused by $R$. solani, and the degree of suppression was directly correlated with total microbial activity. In the $R$. solani system, the length of compost curing positively correlated with disease suppression, and the uncomposted swine waste was conducive to disease (12). The high microbial biomass carbon and microbial biomass nitrogen suggest a high resident population of saprophytic organisms in the CSW medium (12). The medium also contained high population densities of fungi, endospore-forming bacteria, and oligotrophic bacteria (12).

Media containing composted materials may offer multiple mechanisms of biological suppression, thus targeting a wide range of plant pathogens. For example, a medium containing composted sewage sludge was suppressive to Aphanomyces euteiches, Sclerotinia minor, and $R$. solani, whereas another medium containing bark compost was suppressive to P. cinnamomi, Pythium sp., $R$. solani, and Thielaviopsis basicola (25). In general, the mechanisms affecting biological control of Pythium spp. and Phytophthora spp. in compost-amended media differ from those affecting control of $R$. solani (18). A narrow range of organisms is responsible for suppression of Rhizoctonia sp. in compost-amended substrates (10). Perhaps for this reason, only around $20 \%$ of composts suppress Rhizoctonia damping-off, whereas most composts naturally suppress Pythium and Phytophthora root rots (17). Suppression of $R$. solani has been related to the presence of resident strains of Trichoderma spp. and Gliocladium spp. (10) and low levels of available cellulose (11). Unlike Rhizoctonia, Pythium and Phytophthora are considered to be nutrient-dependent pathogens. Nutrient-dependent pathogens are subject to a more general form of suppression, with many organisms contributing to biological suppression in compost-amended media (18). The heightened microbial activity in these compost-amended media prevents germination of pathogen propagules through microbiostasis resulting from nutrient competition $(18,27)$. Because the CSWamended medium offers biological control of diverse pathogens including Rhizoctonia, Pythium ultimum (12), and P. parasitica, it is possible that this medium may incorporate multiple mechanisms of pathogen suppression.
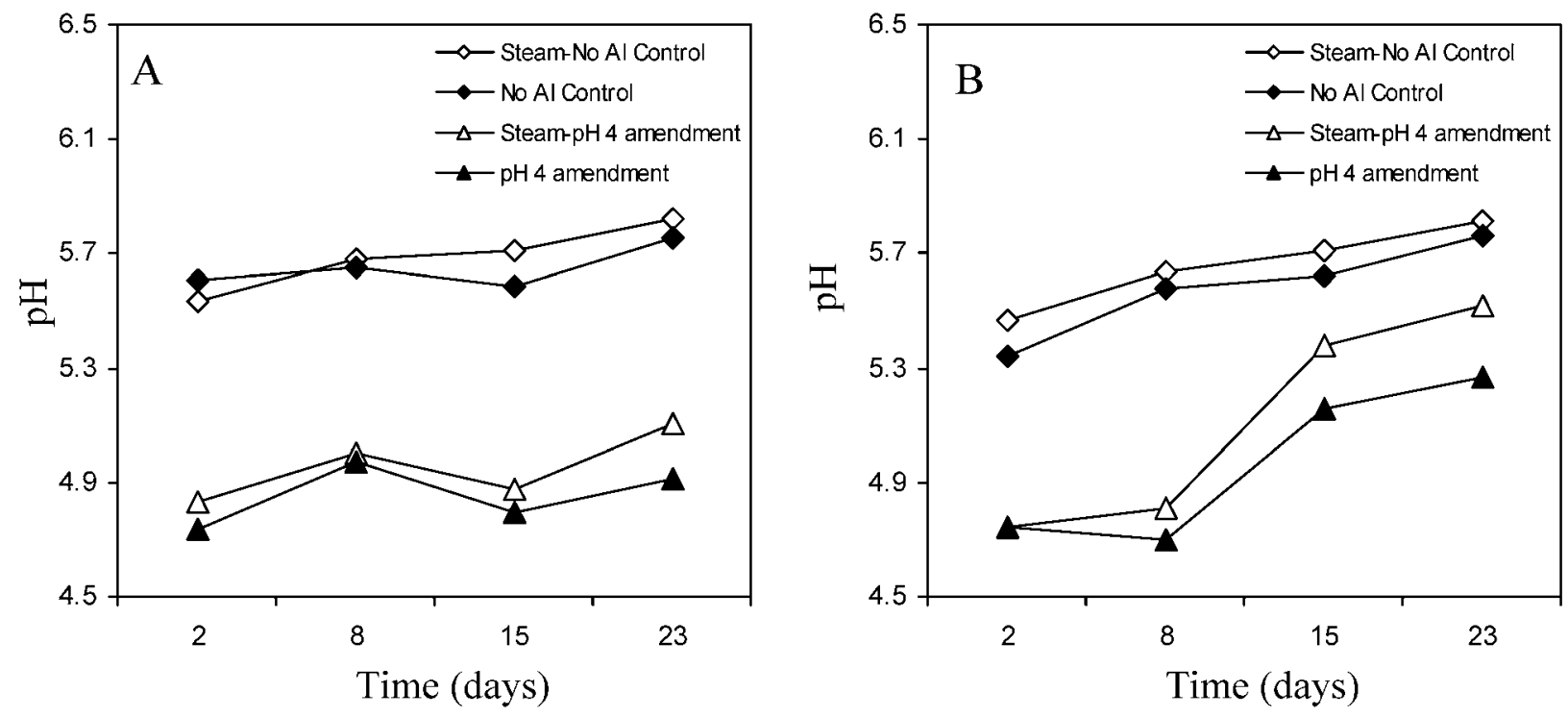

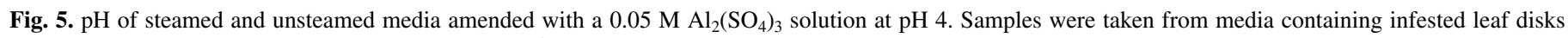
that were buried for $24 \mathrm{~h}$ before funnels were flooded. $\mathbf{A}$ and $\mathbf{B}$ represent separate repetitions of the experiment. 
Steaming had less of an effect on pathogen populations than on sporangium production. A steam effect on pathogen populations was only observed on days 2 and 8 in the first run of the population experiment. Because the infested leaf disks were only submerged in the treated medium for $24 \mathrm{~h}$ prior to flooding, additional data were collected in the second run of the experiment to determine whether $\mathrm{Al}$ or steaming influenced the number of sporangia available at the time of flooding. Steaming had no effect on sporangium production on days 1,7 , and 14 . Therefore, biologically mediated suppression of sporangia production may require more time to occur than the 24 -h period during which the leaf disks were submerged. It is also possible that the steam effect on sporangia production observed on day 22 was related to the presence of a population of microorganisms offering a different or faster mechanism of control. In general, biologically mediated suppression of sporangium production was more consistent on leaf disks buried for $48 \mathrm{~h}$ than on those buried for only $24 \mathrm{~h}$. The efficacy of a longer duration of pathogen contact with the media suggests that nutrient-based competition or microbiostasis may be the predominant mechanism of biological control. Future studies should be designed to address the influence of duration of contact between the pathogen and the compost-amended media on pathogen suppression.

In this system, there was some evidence that $\mathrm{Al}$ interacted with the microbial community and inhibited populations of beneficial microbes. For example, in the population experiment, the steam effect was observed only in media that were not amended with $\mathrm{Al}$. We speculate that Al inhibited the ability of beneficial microbes to compete for nutrients in the system. This hypothesis is supported by the work of Illmer et al. (20), where Al was the main factor inhibiting soil microbial biomass and nitrogen mineralization in forest soils.

In summary, potting medium amended with both CSW and $\mathrm{Al}_{2}\left(\mathrm{SO}_{4}\right)_{3}$ offered both biological and abiotic suppression of $P$. parasitica. The biological and the abiotic factors inhibited sporangium production; however, the two factors may be active at different times. Aluminum inhibited sporangium production on day 2, whereas the biologically mediated suppression of sporangium production persisted from days 8 to 23 . Al amendments may be effective at protecting the plant before beneficial microbial populations reach a threshold necessary for suppression. The documentation of abiotic and biological suppression of $P$. parasitica in a horticultural medium is the first step toward considering and understanding the potential role of these factors in disease suppression.

In addition to suppression of Phytophthora spp., Diab et al. (12) has documented the ability of CSW-amended medium to suppress damping-off caused by $R$. solani. Because biocontrol mechanisms of these two pathogens in compost-amended media are reportedly different (17), the CSW-amended medium may offer multiple mechanisms of biological control. Furthermore, addition of compost to peat-based media may enhance its ability to support an introduced biocontrol agent. The incorporation of abiotic and biocontrol mechanisms may render this medium suppressive to a wide range of soilborne plant pathogens and increase its applicability in a greenhouse-based disease management strategy.

\section{LITERATURE CITED}

1. Andrivon, D. 1995. Inhibition by aluminum of mycelial growth and sporangial production and germination in Phytophthora infestans. Eur. J. Plant Pathol. 101:527-533.

2. Aryantha, I. P., Cross, R., and Guest, D. I. 2000. Suppression of Phytophthora cinnamomi in potting mixes amended with uncomposted and composted animal manures. Phytopathology 90:775-782.

3. Benson, D. M. 1993. Suppression of Phytophthora parasitica on Catharanthus roseus with aluminum. Phytopathology 83:1303-1308.

4. Benson, D. M. 1995. Aluminum amendment of potting mixes for control of Phytophthora damping-off in bedding plants. Hortic. Sci. 30:1413-1416.
5. Bloom, P. R., and McBride, M. B. 1979. Metal ion binding and exchange with hydrogen ions in acid-washed peat. Soil Sci. Soc. Am. J. 43:687692.

6. Boehm, M. J., and Hoitink, H. A. J. 1992. Sustenance of microbial activity in potting mixes and its impact on severity of Pythium root rot on poinsettia. Phytopathology 82:259-264.

7. Chen, W., Hoitink, H. A. J., and Schmitthenner, A. F. 1987. Factors affecting suppression of Pythium damping-off in container media amended with composts. Phytopathology 77:755-760.

8. Chen, W., Hoitink, H. A. J., Schmitthenner, A. F., and Tuovinen, O. H. 1988. The role of microbial activity in suppression of damping-off caused by Pythium ultimum. Phytopathology 78:314-322.

9. Chen, Y., Inbar, Y., and Hadar, H. 1988. Composted agricultural wastes in potting media for ornamental plants. Soil Sci. 145:298-303.

10. Chung, R. Y., and Hoitink, H. A. J. 1990. Interactions between thermophilic fungi and Trichoderma hamatum in suppression of Rhizoctonia damping-off in a bark compost-amended container medium. Phytopathology 80:73-77.

11. Chung, R. Y., Hoitink, H. A. J., Dick, A., and Herr, L. J. 1988. Effects of organic matter decomposition level and cellulose amendment on the inoculum potential of Rhizoctonia solani in hardwood bark media. Phytopathology 78:836-840.

12. Diab, H. G., Hu, S., and Benson, D. M. 2003. Suppression of Rhizoctonia solani on impatiens by enhanced microbial activity in composted swine waste-amended potting mixes. Phytopathology 93:11151123.

13. Fichtner, E. J., Hesterberg, D. L., and Shew, H. D. 2001. Nonphytotoxic aluminum-peat complexes suppress Phytophthora parasitica. Phytopathology 91:1092-1097.

14. Hadar, Y., and Mandelbaum, R. 1992. Suppressive compost for biocontrol of soilborne plant pathogens. Phytoparasitica 20:S113-S116.

15. Hargrove, W. L., and Thomas, G. W. 1982. Titration properties of Al-organic matter. Soil Sci. 134:216-225.

16. Hargrove, W. L., and Thomas, G. W. 1982. Conditional formation constants for aluminum-organic matter complexes. Can. J. Soil Sci. 62:571575.

17. Hoitink, H. A. J., and Boehm, M. J. 1999. Control within the context of soil microbial communities: A substrate-dependent phenomenon. Annu. Rev. Phytopathol. 37:427-446.

18. Hoitink, H. A. J., Inbar, Y., and Boehm, M. J. 1991. Status of compost amended-potting mixes naturally suppressive to soilborne diseases of floricultural crops. Plant Dis. 75:869-873.

19. Huang, J. W., and Kuhlman, E. G. 1991. Mechanisms inhibiting dampingoff pathogens of slash pine-seedlings with a formulated soil amendment. Phytopathology 81:171-177.

20. Illmer, P., Marschall, K., and Schinner, F. 995. Influence of available aluminum on soil micro-organisms. Lett. Appl. Microbiol. 21:393397.

21. Kannwischer, M. E., and Mitchell, D. J. 1978. The influence of a fungicide on the epidemiology of black shank of tobacco. Phytopathology 68:1760-1765

22. Ko, W. H., and Hora, F. K. 1972. Identification of an Al ion as a soil fungitoxin. Soil Sci. 113:42-45.

23. Kuter, G. A., Hoitink, H. A. J., and Chen, W. 1988. Effects of municipal sludge compost curing time on suppression of Pythium and Rhizoctonia diseases of ornamental plants. Plant Dis. 72:731-756.

24. Lewis, J. A. 1973. Effect of mineral salts on Aphanomyces euteiches and a root rot of peas. Phytopathology 63:989-993.

25. Lumsden, R. D., Lewis, J. A., and Millner, P. D. 1983. Effect of composted sewage sludge on several soilborne pathogens and diseases. Phytopathology 73:1543-1548.

26. MacDonald, J. D., and Dunniway, J. M. 1978. Influence of the matric and osmotic components of water potential on zoospore discharge in Phytophthora. Phytopathology 68:751-757.

27. Mandelbaum, R., and Hadar, Y. 1990. Effects of available carbon source on microbial activity and suppression of Pythium aphanidermatum in compost and peat container media. Phytopathology 80:794-804.

28. Marion, G. M., Hendricks, D. M., Dutt, G. R., and Fuller, W. H. 1976. Aluminum and silica solubility in soils. Soil Sci. 121:76-85.

29. Meyer, J. R., and Shew, H. D. 1991. Development of black root rot on burley tobacco as influenced by inoculum density of Thielaviopsis basicola, host resistance, and soil chemistry. Plant Dis. 75:601-605.

30. Meyer, J. R., and Shew, H. D. 1991. Soils suppressive to black root rot of burley tobacco, caused by Thielaviopsis basicola. Phytopathology 81: 946-954.

31. Meyer, J. R., Shew, H. D., and Harrison, U. J. 1994. Inhibition of germination and growth of Thielaviopsis basicola by aluminum. Phytopathology 84:598-602.

32. Meyer, J. R., Shew, H. D., and Shoemaker, P. B. 1989. Populations of Thielaviopsis basicola and the occurrence of black root rot on burley 
tobacco in western North Carolina. Plant Dis. 73:239-242.

33. Nelson, E. B., and Hoitink, H. A. J. 1982. Factors affecting suppression of Rhizoctonia solani in container media. Phytopathology 72:275-279.

34. Stofella, P. J., and Khan, B. A. (eds.) 2000. Compost Utilization in Horticultural Cropping Systems. Lewis Publishers, New York.

35. Vance, G. F., Stevenson, F. J., and Sikora, F. J. 1996. Environmental chemistry of aluminum-organic complexes. Pages 169-220 in: The Envi- ronmental Chemistry of Aluminum. G. Sposito, ed. CRC Press, New York.

36. Yuan, T. L. 1959. Determination of exchangeable hydrogen in soils by a titration method. Soil Sci. 88:164-167.

37. Zibilske, L. M. 1994. Carbon mineralization. Pages 835-864 in: Methods of Soil Analysis, Part 2. Microbiological and Biochemical Properties. SSSA Book Series No. 5. 